Article

\title{
Sustainable Profit versus Unsustainable Growth: Are Venture Capital Investments and Governmental Support Medicines or Poisons?
}

\author{
Moon Young Kang (1) \\ Department of Entrepreneurship and Small Business, College of Business Administration, Soongsil University, \\ Seoul 06978, Korea; mkang@ssu.ac.kr
}

Received: 27 August 2020; Accepted: 18 September 2020; Published: 20 September 2020

check for updates

\begin{abstract}
Considering that startups greatly contribute to the economic development and survival of a country through economic growth and job creation, it is necessary to investigate the profitability of startups. However, research on this issue has not been developed enough as most previous studies regarding firm profitability were based on large-scale public companies with relatively easy data accessibility, not on startups. In addition, it is meaningful to empirically prove whether venture capital investments and governmental support positively impact on the sustainability of startups as huge discrepancies exist between traditional academic research and recent practices. Findings from this study, based on data analytics, are expected to fill the gap in knowledge as it is not clearly known about firm profitability of startups for their sustainable growth and survival. Focusing on startup profitability, the main objective of this research is to provide significant theoretical contributions and practical guidelines for startup entrepreneurs, investors, and policymakers to avoid unsubstantial growth and find solutions for sustainable growth and survival. To properly and completely analyze the determinants of firm profitability of startups, this research used the 2018 and 2019 Survey of Korean Startups by the Ministry of SMEs and Startups of Korea and Korea Venture Business Association with over 3000 samples.
\end{abstract}

Keywords: toxic venture capital; unsustainable growth; governmental support; startup; firm profitability; startup sustainability; data analytics; public data

\section{Introduction}

According to the business model of venture capital, startups raise large-scale funding and use the financial resources for their businesses to grow at a faster than normal speed. Then, larger and more rounds of investments follow. Finally, to sell or to go public brings their early investors great returns on their early investments [1]. Traditionally, it is known that the role of venture capital has positive impacts on the performance of startups by offering financial resources and intangible assets such as networks, management experience, and innovation [1-4].

However, because of the pressure of hyper-growth to pay back a rich and quick liquidity to venture capitals, startups have to chase the marginal monetary gains at great costs with rapidly increasing losses and diminishing returns. Specifically, many startups tend to focus on catering to investors rather than customers, pursue unsustainable growth, which is usually revenue growth without securing sustainable profitability, and pay attention to their exits instead of their own business [5-8]. One of the examples is WeWork, whose equity was valued at $\$ 47$ billion in April 2019, based solely on its upside growth potential without having secure profitability. During the process of IPO (initial public offering), WeWork turned out to be a bubble as the company continued to lose more than two dollars for every dollar of sales (with a net loss of $\$ 1.3$ billion in the third quarter of 2019) and eventually, WeWork 
failed IPO [8,9]. The Economist pointed out the problem of unsustainable growth with poor returns on their investments [8]. Even for successful Unicorns, which are privately-owned startups valued at over $\$ 1$ billion, the priority for survival and sustainable business is firm profitability, not just revenue growth. Therefore, making a profit has become the top priority for Silicon Valley startups [10,11].

According to The Survey of Korean Startups by the Ministry of SMEs and Startups of Korea and Korea Venture Business Association [12,13], the number of employees working for startups in Korea was over 0.7 million people in 2018, which is more than those working in the Top 4 conglomerates in Korea. In addition, the total revenue from the startups was the second largest (KRW 191.9 trillion), following Samsung Electronics. However, their indicators of sustainable profit have continuously diminished including net profit (-24\% for 2018 versus 2017), operating profit margin (from $4.2 \%$ in 2017 to $4.0 \%$ in 2018), and net profit margin (from 3.0\% in 2017 to $2.1 \%$ in 2018). These results indicate that startups in Korea also brought growth in terms of firm size and revenue, but it is questionable whether the growth guaranteed the sustainability of the startups in Korea as in Silicon Valley.

Specifically, considering that startups greatly contribute to the economic development and survival of a country by encouraging economic growth and creating jobs [1,3,14-17], it is necessary to investigate the profitability of startups. However, research on this issue is scant as most previous studies regarding firm profitability were conducted based on large-scale public companies with relatively easy data accessibility through a stock market financial database, not on startups. In addition, it is very meaningful to empirically prove whether the investments of venture capital as well as support from government have a positive influence on the sustainability of startups as vast discrepancies exist between traditional academic research and recent practices. Findings from this study, focusing on startup profitability, are expected to contribute to literature about the firm profitability of startups for their sustainable growth and survival. The main objective of this research is to provide significant theoretical contributions and practical guidelines for startup entrepreneurs, investors, and policymakers to build the virtuous startup ecosystem through avoiding unsubstantial growth and finding solutions for sustainable growth and survival. To properly and completely analyze the determinants of the firm profitability of startups, this research used the 2018 and 2019 Survey of Korean Startups by the Ministry of SMEs and Startups of Korea and Korea Venture Business Association with over 3000 samples.

The rest of this paper is organized as follows. The next section presents theoretical development with relevant literature and hypotheses followed by empirical analysis with detailed information about data and empirical results. Then, this paper provides a conclusion, managerial and theoretical implications, limitations, and future research for startups' sustainable profitability.

\section{Conceptual Background and Development of Hypotheses}

\subsection{Resource-Based View on Firm Profitability}

Firm profitability is an important precondition for firm survival and success [17]. Previous studies and theories on firm profitability are mostly based on the SCP (Structure-Conduct-Performance) model, MBV (Market-based view), and RBV (Resource-based view). While the SCP and MBV take account of the impact of industry characteristics on firm profitability, the RBV emphasizes the role of firm-level unique capabilities and internal resources rather than external factors, having a firm as a unit of analysis [18-23]. According to the RBV, as firms have their own heterogeneous historical path, each firm has different capabilities and resources. In addition, as the resources have the characteristics of immobility, firms can acquire their own core competencies that are hard to copy [18,20]. To focus on the impact of firms' internal factors on their profitability and to conduct firm-level analysis for data availability, this section is based on the Resource-based view [17,24].

The RBV explains a positive relationship between firm size and firm profitability: as firm size grows, it is possible to take advantage of economies of scale and to have more access to resources $[18,20]$. However, the relationship between firm size and firm profitability has not empirically been clearly proven. While some researchers including Salman and Yazdanfar [17] and Jensen and Murphy [25] 
proposed an inverse relationship, others, such as Nune, Serrasqueiro and Sequeira [26], claimed a positive relationship.

Firm growth also has a positive impact on firm profitability as in firm size because increased firm growth makes it possible to access more resources $[18,20]$. However, existing empirical results about the relationship between firm size and firm profitability are mixed. For example, a study by Hoy, McDougall and D'Souza [27] found a negative relationship and that by Markman and Gartner [28] claimed no significant relationship between firm growth and firm profitability. On the other hand, Asimakopoulos, Samitas and Papadogonas [29] and Salman and Yazdanfar [17] found a positive relationship. Moreover, Kang [30] found the positive impact of total asset growth rate and net profit margin growth rate on firm profitability, and insignificant impact of revenue growth rate and operating profit growth rate on firm profitability.

From the perspective of the RBV, firms with higher profitability take advantage of all possible opportunities given to the firm to maximize profit. Therefore, firm profit is related to various cost efficiency and firm productivity factors [18,20]. However, other than Salman and Yazdanfar [17], it is hard to find empirical research to investigate the relationship between firm productivity and firm profitability.

As the main philosophy of the RBV is that firms rely on their own heterogeneous historical path and keep following that path, firms' high profitability from a previous period make them possible to improve cash flow, product/service offerings, and customer relationships. Thus, based on the core competency gained through the improvements, eventually, firms can acquire more resources [18,20]. Regarding the lagged profitability, McDonald empirically found that lagged profitability is the main determinant of firm profitability [31].

According to Autio [32] and Curran et al. [33], firms with longer histories are more likely to overcome limitations of access to resources through more experience, richer information, better reputation, and great networks. While Claver, Molina and Tari [34] found a significant positive impact of firm age on firm profitability, it is still not enough to fully conclude the relationship.

Previous studies have not clearly proven the empirical relationship between firm capabilities/ resources and firm profitability. As discussed above, based on RBV, this research proposes the following hypotheses related to firm size, firm growth, firm productivity, lagged profitability, and firm age:

Hypothesis 1a. The size of a startup has a significantly positive impact on firm profitability.

Hypothesis $\mathbf{1 b}$. The growth of a startup has a significantly positive impact on firm profitability.

Hypothesis 1c. The productivity of a startup has a significantly positive impact on firm profitability.

Hypothesis 1d. The lagged profitability of a startup has a significantly positive impact on firm profitability.

Hypothesis 1e. The firm age of a startup has a significantly positive impact on firm profitability.

\subsection{Investments of Venture Capital}

While Kang [30] found that firm-specific resources including firm growth (total asset growth rate and net profit margin growth rate), firm productivity, lagged profitability, and firm life cycle affect firm profitability, the study did not consider the effect of investments of venture capital and support from government, which can be major forces to promote startups. Since the 1980s, the venture capital industry has grown dramatically. Traditionally, it is known that venture capitals positively influence the development of startups. Previous studies explained that venture capital plays positive roles in connecting various stakeholders and providing financial resources, advanced management, and networks [35-37]. 
However, more recently, there are opposite streams of research claiming that venture capital investments are significantly negatively related to firm performance $[38,39]$. Further, the real effects of venture capital on innovation have been difficult to establish [40,41]. This contradictory situation can be explained by the fact that the financial resources provided by venture capitals might encourage entrepreneurs to make inefficient strategic decisions such as managerial optimism [42,43]. This was empirically proven by George [44] that firm profitability declines when firms have a large amount of assets. In addition, the bubbles and crashes theory also explains the negative relation between venture capital investment and firm performance (e.g., firm productivity). As investments from venture capital increase during economic booms, firm productivity diminishes with the declining economy, and thus, a venture capital investment boom leads to declined firm productivity [45]. Moreover, Engel and Keilbach [46] and Caselli, Gatti and Perrini [47] empirically found that firms experience high revenue growth but a decrease in innovative outputs (e.g., number of patents) after receiving venture capital financing. This can be explained by that venture capitalists may change the investment strategy from innovation to cashing out in order to achieve the rapid liquidation of their investment in IPO or M\&A markets [38]. As this stream of research is relatively new, proliferating since the mid-2000s, and the access to firm-level startup data is relatively limited, academic theories and empirical evidence regarding this issue are not yet rich. However, burgeoning claims exist from the real world that startups have withered due to toxic venture capitals that kill the ecosystem of startups, and, for this reason, an increasing number of entrepreneurs have rejected funding from venture capitals [5-8,48]. Therefore, this research proposes the following hypotheses:

Hypothesis 2a. Venture capital investment in startups has a significantly negative impact on firm profitability.

Hypothesis $\mathbf{2 b}$. An increasing share of venture capital has a significantly negative impact on firm profitability.

\subsection{Support from Government}

In addition to the investments of venture capital, support from government can be a major force which significantly promotes startups and is also another opportunity for startups to acquire resources. The investment decision of venture capitals may differ from the support decisions of governments. Considering startups' spillover effect throughout the economy, governments provide support programs to increase startup rates for nationwide economic development and to foster survival and growth of startups [49], while the objective of venture capital is high returns and rapid liquidation of their investments $[1,5-8,38]$.

Apart from providing direct financial resources, the support from government has been known to play an important role as a signaling effect to other stakeholders, which makes recipient startups able to be considered being certified as legitimate entities and helps them overcome limited resources and relatively short business histories as startups $[50,51]$. Previous research on government subsidies claimed that selective subsidies provide a positive signaling effect to potential capital providers. For example, Lerner [50] and Feldman and Kelley [52] argued that receiving a government research and development (R\&D) subsidy increases the funding from other sources. Given their anticipated contributions to the nation's economy, policymakers provide governmental support such as loans, R\&D subsidies, and government direct venture capital funds as limited partners (LPs) [53,54]. The results concerning the relationship between government subsidies and firm performance are mixed [50,55-57]. The reason may be due to the fact that previous studies did not fully consider different types of governmental support, which may have a different impact on firm profitability. Moreover, a few previous studies regarding outcome additionality were focused on access to financial resources and human resources in terms of firm growth (e.g., growth of revenue and number of employees) rather than firm profitability $[50,52,57,58]$. Therefore, this research proposes the following hypotheses related to support from government: 
Hypothesis 3a. Governmental support has a significant impact on firm profitability.

Hypothesis $3 \mathbf{b}$. Different types of governmental support have different impacts on firm profitability.

\section{Empirical Analysis}

\subsection{Data}

This research analyzed the 2018 and 2019 Survey of Korean Startups by the Ministry of SMEs and Startups of Korea and Korea Venture Business Association, which is meaningful to use the data from a public source (https://www.data.go.kr/). The 2018 and 2019 Survey of Korean Startups were collected through stratified sampling (one of the probability sampling methods) regarding the total of Korean startups (population sizes were 35,186 in 2017 and 36,065 in 2018, and sample sizes were 2059 in 2017 and 1733 in 2018, respectively).

While there may exist diverse variables regarding the dependent variable, firm profitability, as well as the explanatory variables (firm size, firm growth, firm productivity, firm age, venture capital investment, and governmental support), this research selected the following representative variables as shown in Table 1. This was done through carefully considering data accessibility for empirical analysis, correlation between variables, multicollinearity, and previous studies. For more details about the main variables of this study, please see Table 1.

Table 1. Main variables.

\begin{tabular}{|c|c|c|c|}
\hline \multirow{2}{*}{\multicolumn{2}{|c|}{$\begin{array}{c}\text { Category } \\
\text { Dependent Variable and Lagged Variable }\end{array}$}} & \multicolumn{2}{|c|}{ Variables } \\
\hline & & ROA (Return on Asset) & Net Profit/Total Asset $\times 100$ \\
\hline \multirow{10}{*}{$\begin{array}{l}\text { Independent } \\
\text { variables }\end{array}$} & Firm size & Number of employees & Total number of employees \\
\hline & \multirow{4}{*}{ Firm growth } & Revenue growth rate & \multirow{4}{*}{$\begin{array}{c}\text { (Result at current year }- \text { Result at } \\
\text { previous year)/Result at previous } \\
\text { year } \times 100\end{array}$} \\
\hline & & Total asset growth rate & \\
\hline & & Operating profit growth rate & \\
\hline & & Net profit growth rate & \\
\hline & Firm productivity & Operating profit per capita & $\begin{array}{l}\text { Operating profit/Total number } \\
\text { of employees }\end{array}$ \\
\hline & Firm age & \multicolumn{2}{|c|}{ Current year - Year of establishment } \\
\hline & \multirow{2}{*}{$\begin{array}{l}\text { Venture Capital (VC) } \\
\text { investment }\end{array}$} & VC investment dummy & 1 if VC invested, 0 otherwise. \\
\hline & & Share of VC & VC owned equity/Total equity $\times 100$ \\
\hline & Governmental support & \multicolumn{2}{|c|}{1 if government supported, 0 otherwise } \\
\hline \multicolumn{2}{|c|}{ Control variable } & Year & Financial year (2017 and 2018) \\
\hline
\end{tabular}

Table 2 provides descriptive statistics of the main variables used in this study. Through Table 2, it is possible to find that the standard deviation is substantial for firm profitability (ROA-Return on Asset), firm growth (revenue growth rate, total asset growth rate, operating profit growth rate, and net profit growth rate), and firm productivity (operating profit per capita), while the standard deviation is relatively small for firm size (number of employees) and firm age. In the database, there exist three types of governmental support: government loan, government technology guarantee fund, and government $R \& D$ certification. 
Table 2. Descriptive statistics for main variables.

\begin{tabular}{|c|c|c|c|c|c|c|}
\hline & Variables & Unit & Mean & Standard Deviation & Minimum & Maximum \\
\hline & ROA at current year & $\%$ & 0.831 & 34.513 & -982.432 & 223.054 \\
\hline & ROA at previous year & $\%$ & 2.016 & 28.834 & -941.694 & 213.699 \\
\hline Firm size & Number of employees & Count & 61.996 & 91.298 & 1.000 & 2348.000 \\
\hline \multirow{4}{*}{ Firm growth } & Revenue growth rate & $\%$ & 41.052 & 474.596 & -99.934 & $23,150.000$ \\
\hline & Total asset growth rate & $\%$ & 23.865 & 111.751 & -95.919 & 5150.000 \\
\hline & Operating profit growth rate & $\%$ & -9.153 & 1917.261 & $-95,100.000$ & $24,300.000$ \\
\hline & Net profit growth rate & $\%$ & -61.899 & 1730.691 & $-58,250.000$ & $35,020.000$ \\
\hline Firm productivity & Operating profit per capita & Million KRW & 10.119 & 44.360 & -591.800 & 525.500 \\
\hline & Firm age & year & 13.000 & 7.552 & 1.000 & 59.000 \\
\hline \multirow{2}{*}{ VC investment } & VC investment dummy & 0 or 1 & 0.126 & 0.332 & 0.000 & 1.000 \\
\hline & Share of VC & $\%$ & 2.663 & 9.479 & 0.000 & 100.000 \\
\hline \multirow{4}{*}{ Governmental support } & Governmental support dummy & 0 or 1 & 0.926 & 0.262 & 0.000 & 1.000 \\
\hline & Government loan dummy & 0 or 1 & 0.067 & 0.250 & 0.000 & 1.000 \\
\hline & Government technology guarantee fund dummy & 0 or 1 & 0.732 & 0.443 & 0.000 & 1.000 \\
\hline & Government R\&D certification dummy & 0 or 1 & 0.127 & 0.333 & 0.000 & 1.000 \\
\hline
\end{tabular}




\subsection{Empirical Results}

The objective of this research is to investigate the impact of firm-specific characteristics including firm size, firm growth, firm productivity, lagged profitability, firm age, venture capital investments, and governmental support on firm profitability. The results from the regression are reported in Table 3.

Table 3. Empirical results.

\begin{tabular}{|c|c|c|c|}
\hline \multicolumn{2}{|r|}{ Dependent Variable: Current ROA } & Model 1 & Model 2 \\
\hline \multicolumn{2}{|r|}{ Constant } & $-12.108^{* * *}$ & $-11.841 * * *$ \\
\hline Firm size & $\ln$ (total number of employees) & 0.201 & 0.169 \\
\hline \multirow{4}{*}{ Firm growth } & Revenue growth rate & $-0.008 * * *$ & $-0.008^{* * *}$ \\
\hline & Total asset growth rate & $0.057 * * *$ & $0.057^{* * *}$ \\
\hline & Operating profit growth rate & $0.001 * * *$ & $0.001 * * *$ \\
\hline & Net profit growth rate & $0.001^{* * *}$ & $0.001^{* * *}$ \\
\hline \multirow[t]{3}{*}{ Firm productivity } & Operating profit per capita & $0.184^{* * *}$ & $0.184^{* * *}$ \\
\hline & Lagged ROA & $0.300^{* * *}$ & $0.300^{* * *}$ \\
\hline & $\ln$ (firm age) & $2.031 * *$ & $1.995^{* *}$ \\
\hline \multirow{2}{*}{ VC investment } & VC investment dummy & $-4.439 * *$ & $-4.514^{* *}$ \\
\hline & Share of VC & -0.114 * & -0.114 * \\
\hline \multirow{5}{*}{ Governmental support } & Governmental support (vs. no gov. support) & $5.505^{* *}$ & \\
\hline & Government loan (vs. no gov. support) & - & $5.191 *$ \\
\hline & Government technology guarantee fund (vs. no gov. support) & - & $5.299 * *$ \\
\hline & Government R\&D certification (vs. no gov. support) & - & $6.216^{* *}$ \\
\hline & Year dummy & -0.467 & -0.438 \\
\hline
\end{tabular}

${ }^{*}$ Statistically significant at the 0.1 level. ${ }^{* *}$ Statistically significant at the 0.05 level. ${ }^{* * *}$ Statistically significant at the 0.01 level. $\ln =$ natural logarithm.

First, when looking at the results from Model 1 in Table 3, firm size does not have any significant impact on firm profitability ( $\beta=0.201, p>0.10$ ), which rejects our H1a. Then, regarding the impact of firm growth on firm profitability, this research found a significantly positive impact of total asset growth rate $(\beta=0.057, p<0.01)$, operating profit growth rate $(\beta=0.001, p<0.01)$, and net profit growth rate $(\beta=0.001, p<0.01)$, while the impact of revenue growth rate is significantly negative $(\beta=-0.008$, $p<0.01)$. These results align with recent practices in Silicon Valley where making a profit has become the top priority [10,11]. In addition, these results are thought-provoking in that both the growth of net profit, which is a numerator of ROA, and the growth of total assets, which is a denominator of ROA, have significantly positive influences on firm profitability. Next, firm productivity, lagged ROA, and firm age have significant effects on firm profitability, supporting our H1c $(\beta=0.184, p<0.01)$, H1d $(\beta=0.300, p<0.01)$, and H1e $(\beta=2.031, p<0.05)$, respectively. These results are meaningful in that they provide theoretical, empirical, and practical contributions as existing studies have unclear conclusions on the relationship between firm internal factors and firm profitability.

Second, the results show that venture capital investments have a significantly negative impact on firm profitability ( $\beta=-4.439, p<0.05)$, supporting our H2a. In addition, an increase in the share of venture capital also has a slightly negative impact on firm profitability $(\beta=-0.114, p<0.10)$, supporting our $\mathrm{H} 2 \mathrm{~b}$. Moreover, the results from the one-way analysis of variance (ANOVA) from Table 4 also explain that significant differences exist in firm profitability depending on whether a startup is venture capital-backed $(\mathrm{F}(1,3790)=83.142, p<.001)$. While the mean ROA of venture capital invested startups is negative $(-12.482)$, that of startups that are not backed by venture capital is positive (+2.751). These results confirm the recent stream of research as well as increasing voices from the startups claiming that venture capital investments are significantly negatively related to firm 
sustainability and that the investment of venture capital is toxic [5-8,38-41,44-48]. This is contradictory to traditional positive perspectives [35-37].

Table 4. Firm profitability of VC invested startups versus VC non-invested startups.

\begin{tabular}{cccccc}
\hline & N & Mean & Std. Deviation & Minimum & Maximum \\
\hline VC invested startups & 478 & -12.482 & 54.373 & -787.340 & 53.460 \\
VC non-invested startups & 3314 & 2.751 & 30.134 & -982.430 & 223.050 \\
Total & 3792 & 0.831 & 34.513 & -982.430 & 223.050 \\
\hline
\end{tabular}

Lastly, regarding governmental support, the results support our $\mathrm{H3a}$, which posits that governmental support has a significant impact on firm profitability $(\beta=5.505, p<0.05)$. In addition, the results from the one-way analysis of variance (ANOVA) from Table 5 also confirm that there is a significant difference in firm profitability depending on whether a startup received support from the government $(\mathrm{F}(1,3790)=65.360, p<.001)$. While the mean ROA of startups with governmental support is positive (+2.099), that of startups without governmental support is negative $(-15.082)$.

Table 5. Firm profitability of startups with government support versus without government support.

\begin{tabular}{cccccc}
\hline & N & Mean & Std. Deviation & Minimum & Maximum \\
\hline Startups with government support & 280 & -15.082 & 63.390 & -787.342 & 36.668 \\
Startups without government support & 3512 & 2.099 & 30.741 & -982.432 & 223.054 \\
Total & 3792 & 0.831 & 34.513 & -982.432 & 223.054 \\
\hline
\end{tabular}

Now, when moving on to the results from Model 2 in Table 3, the results show that each type of governmental support has a different impact on firm profitability, supporting our H3b. Government R\&D certification has the largest impact on firm profitability $(\beta=6.216, p<0.05)$ followed by government technology guarantee fund $(\beta=5.299, p<0.05)$ and government loan $(\beta=5.191$, $p<0.10$ ). These results are in line with a recent announcement by the Government of Korea in the Act on the Special Measures for Venture Business Fostering, in which the government will discontinue government technology guarantee funds and government loans (effective in February 2021). The results from this study point to the fact that the support from the government is a kind of medicine (positive effect) while the investment of venture capital is toxic (negative effect).

\section{Conclusions and Discussion}

Considering the substantial economic contribution of startups including economic growth and job creation, it is necessary to investigate the profitability of startups. However, research on this issue has not been properly developed. In addition, as huge discrepancies exist between traditional and more current research streams, it is very meaningful to empirically prove whether venture capital investments as well as governmental support are beneficial (a medicine) or harmful (toxic) for the sustainability of startups. Focusing on startup profitability, the main objective of this research is to provide significant theoretical and empirical contributions as well as practical guidelines for startup entrepreneurs, investors, and policymakers to avoid unsubstantial growth and find solutions for sustainable growth and survival. By analyzing the 2018 and 2019 Survey of Korean Startups by the Ministry of SMEs and Startups of Korea and Korea Venture Business Association, the findings from this study are expected to contribute to academic research by extensively investigating the firm profitability of startups for their sustainable growth and survival. First, while firm size does not have any significant impact on firm profitability, firm growth (excluding revenue growth rate), firm productivity, lagged profitability, and firm age have a significantly positive impact on firm profitability. Second, investments from venture capital and increasing share of venture capital have a significantly negative impact on firm profitability. Third, governmental support has a significant impact on firm 
profitability. Among the different types of governmental support, government R\&D certification has a greater effect on firm profitability than government technology guarantee funds and government loans.

The results from this study provide implications for startup entrepreneurs, investors, and policymakers. It is important to avoid unsubstantial growth, which is rapid revenue growth without securing sustainable profitability, and focus on the sustainable growth and survival. Especially, instead of being obsessed with investor management, startup entrepreneurs need to make solid business and revenue models with virtuous cycles for their sustainability. Without acquiring solid startup profitability, there is no future for economic survival and growth as well as successful exit for investors and entrepreneurs. To make the virtuous startup ecosystem, the roles of venture capitalists and policymakers are important. For example, instead of chasing greedy returns on their investments through hyper-growth, venture capitals invest in "real business" with portfolios having healthy business models and solid profitability [7]. In addition, governmental support should be carefully considered against possible negative effects and strategically complement the pitfalls of the market economy considering its spillover effects throughout the economy.

There were some limitations in conducting this research. First, this research is limited to data from the 2018 and 2019 Survey of Korean Startups. While it is meaningful to analyze startup data by using a public database, researchers may not have enough freedom to investigate comprehensive variables regarding industry, market, and firm. For this reason, this study was mainly based on the Resource-based view [18-23]. However, future research may investigate various comprehensive models of industry, market, and firm. Second, while this research is focused on cross-sectional data, it will be also interesting to analyze time series data to decide optimal strategies of startups, venture capitals, and governments based on the venture industry life cycle and economic cycle. Third, this research used startup profitability as a dependent variable as many startups are not listed on the stock market. However, how to measure and determine the dependent and independent variables for startup sustainability is very important [59]. Future research can develop various unbiased, forward-looking, risk-adjusted capital market-based measures of startup sustainability.

Funding: This research received no external funding.

Conflicts of Interest: The author declares no conflict of interest.

\section{References}

1. Zider, B. How venture capital works. Harv. Bus. Rev. 1998, 76, 131-139. [PubMed]

2. Barry, C.B.; Muscarella, C.J.; Peavy, J.W., III; Vetsuypens, M.R. The role of venture capital in the creation of public companies: Evidence from the going-public process. J. Financ. Econ. 1990, 27, 447-471. [CrossRef]

3. Kortum, S.; Lerner, J. Assessing the contribution of venture capital to innovation. RAND J. Econ. 2000, 31, 674-692. [CrossRef]

4. Hellmann, T.; Puri, M. Venture capital and the professionalization of start-up firms: Empirical evidence. J. Financ. 2002, 57, 169-197. [CrossRef]

5. Paley, E. Toxic VC and the Marginal-Dollar Problem. Techcrunch, 2017. Available online: https: //techcrunch.com/2017/10/26/toxic-vc-and-the-marginal-dollar-problem/2017/10/26/toxic-vc-and-the-mar ginal-dollar-problem/ (accessed on 1 August 2020).

6. Phillips, F. The sad state of entrepreneurship in America: What educators can do about it. Technol. Forecast. Soc. 2018, 129, 12-15. [CrossRef]

7. Goetz, T. Want Your Startup to Succeed? Follow the Microsoft and Mailchimp Path by Taking Less Money. Inc. Magazine, 2018. Available online: https://www.inc.com/magazine/201804/thomas-goetz/venture-capital -investing-profit.html (accessed on 1 August 2020).

8. A stampede of mythical proportions. The Wave of Unicorn IPOs Reveals Silicon Valley's Groupthink. The Economics. Available online: https://www.economist.com/briefing/2019/04/17/the-wave-of-unicorn-iposreveals-silicon-valleys-groupthink (accessed on 1 August 2020). 
9. Platt, E. WeWork Losses Doubled as It Rushed to Open New Offices Ahead of Its Failed IPO. Los Angeles Times, 2019. Available online: https://www.latimes.com/business/story/2019-11-13/wework-losses-jumped-ahead-o f-failed-ipo (accessed on 1 August 2020).

10. Cristea, I.A.; Cahan, E.M.; Ioannidis, J.P.A. Stealth research: Lack of peer-reviewed evidence from healthcare unicorns. Eur. J. Clin. Investig. 2019, 49, e13072. [CrossRef] [PubMed]

11. Griffith, E. Silicon Valley is Trying Out a New Mantra: Make a Profit. New York Times, 2019. Available online: https://www.nytimes.com/2019/10/08/technology/silicon-valley-startup-profit.html (accessed on 1 August 2020).

12. Ministry of SMEs and Startups of Korea. 2018 Survey of Korean Startups. 2018. Available online: https://www.data.go.kr/data/3043469/fileData.do (accessed on 1 August 2020).

13. Ministry of SMEs and Startups of Korea. 2019 Survey of Korean Startups. 2019. Available online: https://www.data.go.kr/data/3043469/fileData.do (accessed on 1 August 2020).

14. Decker, R.; Haltiwanger, J.; Jarmin, R.; Miranda, J. The role of entrepreneurship in US job creation and economic dynamism. J. Econ. Persp. 2014, 28, 3-24. [CrossRef]

15. Fritsch, M.; Schindele, Y. The contribution of new businesses to regional employment-An empirical analysis. Econ. Geogr. 2011, 87, 153-180. [CrossRef]

16. Haltiwanger, J.; Jarmin, R.S.; Miranda, J. Who creates jobs? Small versus large versus young. Rev. Econ. Stat. 2013, 95, 347-361. [CrossRef]

17. Salman, A.K.; Yazdanfar, D. Profitability in Swedish SME firms: A quantile regression approach. Int. Bus. Res. 2012, 5, 94-106. [CrossRef]

18. Wernerfelt, B. A resource-based view of the firm. Strateg. Manag. J. 1984, 5, 171-180. [CrossRef]

19. Porter, M.E. Competitive Advantage: Creating and Sustaining Superior Performance; The Free Press: New York, NY, USA, 1985.

20. Barney, J. Firm resources and sustained competitive advantage. J. Manag. 1991, 17, 99-120. [CrossRef]

21. Mahoney, J.; Pandian, J. The resource-based view within the conversation of strategic management. Strateg. Manag. J. 1992, 13, 363-380. [CrossRef]

22. Amit, R.; Schoemaker, P. Strategic assets and organizational rent. Strateg. Manag. J. 1993, 14, 33-46. [CrossRef]

23. Makhija, M. Comparing the resource-based and market-based views of the firm: Empirical evidence from Czech privatization. Strateg. Manag. J. 2003, 24, 433-451. [CrossRef]

24. Schiniotakis, N.J. Profitability factors and efficiency of Greek banks. Euro Med. J. Bus. 2012, 7, $185-200$. [CrossRef]

25. Jensen, M.C.; Murphy, K.J. Performance pay and top-management incentives. J. Polit. Econ. 1990, 98, $225-264$. [CrossRef]

26. Nunes, P.J.M.; Serrasqueiro, Z.M.; Sequeira, T.N. Profitability in Portuguese service industries: A panel data approach. Serv. Ind. J. 2019, 29, 693-707. [CrossRef]

27. Hoy, F.; McDougall, P.P.; D'Souza, D.E. Strategies and environments of high-growth Firms. In The State of the Art of Entrepreneurship; Sexton, D.L., Kasarda, J.D., Eds.; PWS-Kent: Boston, MA, USA, 1992; pp. 341-357.

28. Markman, G.D.; Gartner, W.B. Is extraordinary growth profitable? A study of Inc. 500 high-growth companies. J. Entrepr. Theor. Pract. 2002, 27, 65-75. [CrossRef]

29. Asimakopoulos, I.; Samitas, A.; Papadogonas, T. Firm-specific and economy wide determinants of firm profitability: Greek evidence using panel data. Manag. Financ. 2009, 35, 930-939. [CrossRef]

30. Kang, M.Y. Determinants of startup profitability: Implications for Korean startups. J. Prod. Res. 2020, 38, 7-12.

31. McDonald, J. The determinants of firm profitability in Australian manufacturing. Econ. Rec. 1999, 75, 115-126. [CrossRef]

32. Autio, E. Creative tension: The significance of Ben Oviatt's and Patricia McDougall's article 'Toward a theory of international new ventures'. J. Int. Bus. Stud. 2005, 36, 9-19. [CrossRef]

33. Curran, J.; Jarvis, R.; Blackburn, R.A.; Black, S. Networks and small firms: Constructs, methodological strategies and some findings. Int. Small Bus. J. 1993, 11, 13-24. [CrossRef]

34. Claver, E.; Molina, J.; Tari, J. Firm and industry effects on firm profitability: A Spanish empirical analysis. Eur. Manag. J. 2002, 20, 321-328. [CrossRef]

35. Gompers, P.; Lerner, J. An analysis of compensation in the US venture capital partnership. J. Financ. Econ. 1999, 51, 3-44. [CrossRef] 
36. Hellmann, T.; Puri, M. The interaction between product market and financing strategy: The role of venture capital. Rev. Financ. Stud. 2000, 13, 959-984. [CrossRef]

37. von Burg, U.; Kenney, M. Venture capital and the birth of the local area networking industry. Res. Policy 2000, 29, 1135-1155. [CrossRef]

38. Hirukawa, M.; Ueda, M. Venture capital and innovation: Which is first? Pacif. Econ. Rev. 2011, 16, 421-465. [CrossRef]

39. Peneder, M. The impact of venture capital on innovation behaviour and firm growth. Int. J. Entrepr. Financ. 2010, 12, 83-107. [CrossRef]

40. Hall, B.H.; Lerner, J. The financing of R\&D and innovation. In Handbook of the Economics of Innovation; Hall, B.H., Rosenberg, N., Eds.; Elsevier: Oxford, UK, 2010; pp. 609-639.

41. Dessí, R.; Yin, N. The impact of venture capital on innovation. In Oxford Handbook of Venture Capital; Cumming, D., Ed.; Oxford University Press: Oxford, UK, 2012; pp. 668-685.

42. Kahneman, D.; Lovallo, D. Timid choices and bold forecasts. Manage. Sci. 1993, 39, 17-31. [CrossRef]

43. deMeza, D.; Southey, C. The borrower's curse: Optimism, finance and entrepreneurship. Econ. J. 1996, 106, 375-386. [CrossRef]

44. George, G. Slack resources and the performance of privately held firms. Acad. Manag. J. 2005, 48, 661-676. [CrossRef]

45. Abreu, D.; Brunnermeier, M.K. Bubbles and crashes. Econometrica 2003, 71, 173-204. [CrossRef]

46. Engel, D.; Keilbach, M. Firm level implications of early stage venture capital investment: An empirical investigation. J. Emp. Financ. 2007, 14, 150-167. [CrossRef]

47. Caselli, S.; Gatti, S.; Perrini, F. Are venture capitalists a catalyst for innovation? Eur. Financ. Manage. 2009, 15, 92-111. [CrossRef]

48. Griffith, E. More Start-Ups Have an Unfamiliar Message for Venture Capitalists: Get Lost. The New York Times, 2019. Available online: https://www.nytimes.com/2019/01/11/technology/start-ups-rejecting-venture-capital. html (accessed on 1 August 2020).

49. Westhead, P.; Storey, D.J. Financial constraints on the growth of high technology small firms in the United Kingdom. Appl. Financ. Econ. 1997, 7, 197-201. [CrossRef]

50. Lerner, J. The government as venture capitalist: The long-run impact of the SBIR program. J. Bus. 1999, 72, 285-318. [CrossRef]

51. Kleer, R. Government R\&D subsidies as a signal for private investors. Res. Policy 2010, 39, 1361-1374.

52. Feldman, M.; Kelley, M. The ex-ante assessment of knowledge spillovers: Government R\&D policy, economic incentives and private firm behavior. Res. Policy 2006, 35, 1509-1521.

53. Brown, J.D.; Earle, J.S. Finance and growth at the firm level: Evidence from SBA loans. J. Financ. 2017, 72, 1039-1080. [CrossRef]

54. Hottenrott, H.; Richstein, R. Start-up subsidies: Does the policy instrument matter? Res. Policy 2020, 49, 103888. [CrossRef]

55. Girma, S.; Görg, H.; Strobl, E. The effects of government grants on plant survival: A micro-econometric analysis. Int. J. Ind. Org. 2007, 25, 701-720. [CrossRef]

56. Hall, B.J.; Maffioli, A. Evaluating the impact of technology development funds in emerging economies: Evidence from Latin America. Eur. J. Develop. Res. 2008, 20, 172-198. [CrossRef]

57. Koski, H.; Pajarinen, M. The role of business subsidies in job creation of start-ups, gazelles and incumbents. Small Bus. Econ. 2012, 41, 195-214. [CrossRef]

58. Achtenhagen, L.; Naldi, L.; Melin, L. "Business growth"-Do practitioners and scholars really talk about the same thing? Entrepreneurship 2010, 34, 289-316. [CrossRef]

59. Buffarta, M.; Croidieub, G.; Kim, P.H.; Bowmand, R. Even winners need to learn: How government entrepreneurship programs can support innovative ventures. Res. Policy 2020, 49, 104052. [CrossRef]

(C) 2020 by the author. Licensee MDPI, Basel, Switzerland. This article is an open access article distributed under the terms and conditions of the Creative Commons Attribution (CC BY) license (http://creativecommons.org/licenses/by/4.0/). 